\title{
New Life Memberships
}

In 1997, the International Phonetic Association's by-laws were revised to recognize as Life Members those members who have paid membership dues for over 30 years. The awarding of Life Membership is intended to honour the impressive records of service of long-time IPA members, and to acknowledge their contribution in a symbolic and in a practical way.

Life Membership was conferred on the following IPA members in 2000:

Dr. Corinne Adams, Sydney

Prof. David Crystal, Anglesey

Prof. John Laver, Edinburgh

Prof. Michael MacMahon, Glasgow

Prof. Peter Roach, Reading

Congratulations are extended to all new Life Members on behalf of the Association.

John H. Esling, Secretary

\section{In Memoriam}

Beatrice Honikman, known informally as "Trixie", was born in 1905 and died in 1997 in Cape Town, South Africa. After graduating and then obtaining an MA there, she moved to University College London where she enrolled at the Department of Phonetics. Daniel Jones clearly thought very highly of her abilities. After his most treasured colleague Lilias Armstrong suddenly died in 1937, it was to Honikman that he entrusted the editing of her uncompleted MS on The Phonetic and Tonal Structure of Kikuyu. Her "helpful suggestions" were acknowledged by Jones in his Outline of English Phonetics, his Pronunciation of English and his book on The Phoneme. After a spell at the University of Hamburg and teaching at her alma mater she returned to the UK, firstly to London to work at the School of Oriental and African Studies, and ultimately to a lectureship at the Leeds University Department of Phonetics. She was held in affectionate regard by her students and colleagues alike. She was an outstanding practical teacher. Her demonstrations of African click sounds in particular were memorably "to the manner born". She published very little but no account of paralinguistic speech phenomena is complete without reference to the famous article on "Articulatory Settings" which she contributed to the 1964 volume of papers In Honour of Daniel Jones.

JWL

Jean-Paul Vinay, born July 18, 1910, died April 10, 1999. He had been a member of the IPA since 1945. Vinay was one of Canada's most eminent linguists and scholars, who profoundly influenced the development of translation, second-language instruction, and general linguistics. He completed the licence in English philology at the Sorbonne in 1932 and an M.A. in Phonetics at University College London in 1937. In 1946, he 
became head of the Department of Linguistics and Translation at the Universite de Montréal. In addition to phonetic work on Montagnais (Chipewyan/Cree) and Welsh, he directed the bilingual Canadian Dictionary project. His popular CBC television course "Speaking French" ran for 10 years. In 1967 he moved to Victoria, where he founded the Department of French and the Department of Linguistics, and became Dean of the Faculty of Arts \& Science. He was awarded doctorates by the University of Ottawa and Concordia University. His many honours include Officier d'Académie (Palmes académiques), Chevalier de la Légion d'Honneur, Fellow of the Royal Society of Canada, Member of the Order of Canada, recipient of the Canadian Confederation Medal, the Queen's Jubilee Medal and the 125th Anniversary of Canada Medal. He retired from the University of Victoria in 1976.

JE

Julian Talbot Pring was born in London on 28 October 1913 and died in Athens where he lived in December 2000. He graduated from Oxford in 1936, and became a member of the staff at University College London in 1944. He retired as Reader in Phonetics in 1979. He was the author of several books on Greek, and of Colloquial English pronunciation. London: Longman, 1959. He was of a generation that expected colleagues to address one another by sumame, and always called me "Wells". He had strong views on standards in pronunciation teaching, and would not tolerate (for example) intrusive [r]. He considered that education should be a matter of inculcating decent standards. He was the last member of staff at UCL phonetics to maintain the [0o / ग:] contrast, distinguishing 'floor' vs. 'flaw'. When I first visited Greece in $1960 \mathrm{I}$ learnt a lot of Greek from his Grammar and phrasebook.

JW

Alvin M. Liberman, born 10 May 1917, died 13 January 2000. He was a former President and Director of Research at Haskins Laboratories in New Haven, Professor Emeritus of Psychology at the University of Connecticut and of Linguistics at Yale University. Dr. Liberman and his colleagues at Haskins discovered many of the main perceptual cues to the consonants and vowels of English. These cues later served to guide the development of artificial speech synthesis, now widely used for machine to human communication. He held that human listeners are biologically adapted to decode the continuously variable signal of running speech and to recover its discrete phonemic components. During the 70 s and $80 \mathrm{~s}$, Dr. Liberman increasingly collaborated with his wife, the late Dr. Isabelle Yoffe Liberman, and other Haskins scientists on reading. They showed that children who have difficulty in learning to read almost always lack "phoneme awareness": they cannot easily learn to break a word into its component consonants and vowels. The critical requirement of phoneme awareness for learning to read alphabetic print is now internationally recognized, in large part due to the two Libermans' passionate advocacy of the "alphabetic principle" against the "whole word," or "sight reading" method of instruction.

MSK and PL 
Gordon Frederick Arnold, born 22 January 1920, died 30 December 1999. He was formerly Reader in Phonetics at University College London and Senior Tutor. As an undergraduate Amold read French, but his studies were interrupted by war service. When he graduated, in 1947, Daniel Jones appointed him Assistant Lecturer, on the recommendation of his teacher of French phonetics, Helene Coustenoble. He took early retirement in 1982 with the title Emeritus Reader in Phonetics. He is best known academically for his co-authorship of O'Connor and Arnold, Intonation of Colloquial English (Longman, 1961; second edition 1973), a successful textbook that also exerted considerable theoretical influence.

Victoria A. Fromkin, born 16 May 1923, died January 19 2000. She was a former Vice Chancellor of UCLA and Professor of Linguistics Emerita. A scholar with a wide array of fields within linguistics, including the brain and language, the linguistic significance of speech errors, and psycholinguistics, she began her academic career in phonetics, basing her Ph.D. thesis on an electromyographic study of the lips. She compiled a major collection of speech errors and slips of the tongue produced spontaneously in normal conversation and by brain-damaged patients to better understand the mental representation of language. Among her many publications, Dr. Fromkin is the senior co-author of the best-selling textbook, "An Introduction to Language," which has been translated into six languages.

PL

The Secretary has also been notified of the deaths of Professor Erik H. Erämetsä, Turku (September1999) and Mr. Lewis C. Evison, Yorkshire (February 2000). 